\title{
EMOTIONAL INTELLIGENCE AND DELINQUENT BEHAVIOUR AMONG SECONDARY SCHOOL STUDENTS IN OBIO-AKPOR LOCAL GOVERNMENT AREA OF RIVERS STATE, NIGERIA
}

\author{
Fabianmartins Obungwah ${ }^{\mathrm{i}}$ \\ $\mathrm{PhD}$, Post Graduate School, \\ Ignatius Ajuru University of Education, \\ Faculty of Education, \\ Department of Educational Psychology, Guidance and Counselling \\ Port Harcourt, Nigeria
}

\begin{abstract}
:
This study examined emotional intelligence and delinquent behaviour among secondary school students in Obio-Akpor Local Government Area of Rivers State. A correlational research design was adopted for the study. Three purposes of study, three research questions and three hypotheses guided the study. The population of the study consisted of all the senior secondary school students in the 20 senior secondary schools in ObioAkpor Local Government area. The population was 17,227. The instrument was subjected to face validity by the researcher's supervisor and two experts in the field of Measurement and Evaluation. The reliability of the instruments was determined through the use of the Cronbach Alpha Method. The following reliability indices were obtained namely: SEII $(r=0.67)$ and SDBI ( $r=0.80)$. Pearson Product Moment Correlation was used to answer all the research questions and also used to test all the hypotheses. Results of the hypotheses were tested for significance at 0.05 alpha level. The finding of the study revealed that self-awareness, social awareness and emotional maturity had no significant relationship with delinquent behaviour of students as such the three hypotheses stated in null form were retained. Based on these findings, it was concluded that proper selfawareness, social awareness and emotional maturity as part of emotional intelligence play some major role in students' delinquent behaviour in secondary schools. Recommendations were made, that teachers should acquire adequate information about students and help students in managing their emotions, policymakers should formulate educational programmes with specific reference to emotional intelligence to address student's antisocial behavioural tendencies.
\end{abstract}

Keywords: emotional intelligence, delinquent behaviour, self-awareness, social awareness, emotional maturity, emotions

i Correspondence: email ofabianmartins@gmail.com 


\section{Introduction}

It is a common practice and observation by teachers and educators in schools, that during play periods some schoolchildren act in cruel ways that make other students avoid them, some on the other hand act gently and most times will want to play aloof as loners which the psychologist termed as introverts. It is another common observation that these students termed "introverts or loners" are not really introverted but always act carefully taking into consideration the emotions and reactions of other students which undeniably is linked to Emotional Intelligence (EI).

Emotional Intelligence (EI) is most often defined as the ability to perceive, use, understand, manage and handle emotions properly. People with high emotional intelligence can recognize their own feelings, and those of others, use emotional information to guide thinking and behavior, discern between different feelings and label them appropriately and adjust emotions to adapt to the environments. To this end, it is assumed that students who act in cruel manner lack feelings and are insensitive to their environment.

Psychologists and sociologists like Thorndike, Adler, and Osange have argued that the basic factors influencing human behaviour are heredity and the environment. The environmental factors may include the physical or geographical places an individual finds himself, such as the family as well as other outward characteristics. On the other hand, hereditary factors which may include genetic factors like intelligence quotient, emotional intelligence (EI), etc. also may play a bigger role in determining behavioural patterns but behaviours are basically of two types, socially acceptable behaviours as well as the anti-social behaviours. Such anti-social behaviours form parts of which are the dependent variables of the present study. Such behaviours are likely manifested during the adolescent period and are referred to as delinquent behaviours. Delinquency according to Kaiban (2015) refers to an offence or misdeed usually of a minor nature especially one committed by a young person. Delinquency otherwise referred to as juvenile delinquency is mostly associated with adolescents,

Adolescents at some point or the other manifest behaviour which may be connected with some factors. As discussed earlier, some of such factors could be caused by the environment while others could be caused by heredity. While some experts have widely attributed the cause of delinquency to environmental factors like peer group, location, parental upbringing etc. Some on the other hand like Duisenberg (2019) have attributed some delinquent behaviour to insensitivity and genetically issues.

Emotional intelligence as the independent variable of the study is one of the natural and at times acquired characteristics that make it possible for individuals to master or sense specific situations even before such situations manifest. It involves an individual's ability to adjust to various environmental demands. Parker, et al. (2012) noted that emotional intelligence is a state of being sensitively stable in a way that enables one to have an understanding of self and others (interpersonal relationship) as well as 
the ability to effectively utilize one's feelings which in turn may result in a positive emotional change.

Self-awareness, social awareness and emotional maturity are basic constructs of emotional intelligence that interplay with delinquent behaviours and can determine the degree of response to antisocial behaviours. Goleman (2016) asserted that emotional intelligence is the ability to identify, understand, use and manage a person and others emotional state effectively. It involves the intellectual process that leads to the use of emotional feelings to motivate, plan and achieve. Hence one can see emotional intelligence as an interconnection between feelings and things. Golemn (2016) further stated that emotional intelligence (El) is an individual's ability to perceive, understand and use their own emotional status, leading to effectiveness, research have indicated that El plays a significant role in the organization, direction and motivation of human activities. It is highly significant in the development of human potentials, teamwork, effective leadership, stress reduction, creativity and innovation (Chopra \& Kanji, 2010).

Bullying as a variable under delinquency is a delinquent behaviour that involves unwanted aggressive behaviour among school-aged children that involves a real or perceived power imbalance. Bullying may include actions like making threats, namecalling, hitting etc. it involves voluntary use of force or threat to coerce, abuse, intimidate or aggressively dominate other people. Various adolescents with serious characteristics at times intimidate weaker children; in the school setup such attitude could be connected with the emotional intelligence of either the bully or the bullied. Perhaps, children who cannot control their temper may end up throwing punches at their fellow students which may make them fearful or feel inferior. Fighting otherwise termed "affrony" in this study refers to a violent and noisy light, especially in public places (Homby, 2015). Fighting, on the whole, is also a delinquent behaviour that manifests in almost the everyday life of the adolescent. Adolescents fight in schools, in the house, in the neighborhood etc. It may not be out of place if one opines that fighting is connected to lack of emotional intelligence or even over possession of emotional intelligence. It could be that the inability of adolescents to understand their fellow adolescents may be responsible for fighting behaviour which they display at every point in time and these antisocial behaviours are a reflection of poor self-awareness, poor social awareness and poor emotional maturity.

\subsection{Statement of the Problem}

Learners who are emotionally balanced are always active; they try to get ready whenever they are learning. Students' delinquent behaviours account for a series of problems encountered in the teaching-learning process. This is evidenced within and outside the classroom environment, for instance, a student who is insensitive and does not consider how their teacher may feel may likely come to school late. The resulting punishment may likely lead to truancy, aggressiveness, bullying and other vices experienced in the school environment.

More emphatically is that such behaviours like bullying, truancy, lateness to school, stealing, drug abuse and fighting have contributed in no small measure to the 
reduction of the glory of secondary school education in Nigeria (especially in public schools) which in turn have constantly affected the effort towards national development such as culture, moral values, economy technology and general productivity. However, delinquent behaviours have fast metamorphosed into the life of secondary school students which needs adequate attention. Being bullied by other students may lead some students into joining bad gangs, cult groups and other hand influences which they may seek in order to avoid the bullies and persons with delinquent behaviours.

Having considered the various vices prevalent in the society, the problem of the study is "could lack emotional intelligence predict such delinquent behaviour experienced in the secondary school today or society at large?" Yes, there could be other related factors that actually exist as predictors of delinquent behaviours. Thus, this research is to consider the emotional intelligence and delinquent behaviour among secondary school students in Obio-Akpor Local Government Area of Rivers State, in which the result will act as an implication for curriculum planners, instructional designers, Special Needs Educators, Guidance Counsellors and Psychologists.

\subsection{Significance of the Study}

The result of this study will be of great benefit to these categories of individuals: Students, Guidance Counsellors, Parents, Government, Non-Governmental Organisation (NGO), Religious Organisation, School Administration and Future Researchers.

- Students: The finding of this study would help students (male and female) to discover the dangers of delinquent behaviours, the consequences of negative thoughts and behaviours. The study will help them in managing their negative thoughts and actions. It will help the students to become better in the school environment and society at large.

- Guidance Counsellors: The outcome of this investigation will be relevant to counsellors in rightly predicting the causes of students' poor emotional intelligence, delinquent behaviours and poor academic achievement. The counsellor would be able to know if the factors are resident in the school children or as a result of external factors. Students who lack emotional intelligence are likely to perform poorly acts that are against the rules and regulations of the school and society at large.

- Parents: The study will help parents to have a closer relationship with their children to ensure positive emotion which will enhance greater emotional intelligence and higher academic achievement.

- Government: The finding of the study will serve as an eye-opener to the state and federal ministry of education in guiding the behaviours of secondary school students and in formulating curricula that will affect the academic achievement of secondary school students in Obio-Akpor Local Government Area of Rivers State.

- NGOs: This study will enhance NGOs in understanding the emotional needs of the society and in the administration of psychological remedies to curb the menace of egoistic and tribalistic traits amongst youths and students in the society. 
- School Administration: The study will assist school management in handling some behavioural problems such as lack of discipline, underachievement, bullying, school violence, attrition, absenteeism, drug abuse, lack of motivation and psycho-educational problems

- Future Researchers: Finally, the findings of this study will add to existing research materials which will enable easy future studies by students/researchers. The information contained in this study will also act as reference material for future researchers.

\subsection{Purpose of the Study}

The purpose of the study was to examine emotional intelligence and delinquent behaviour among Secondary School Students. Specifically, the study intended to;

1) Determine the extent of the relationship between self-awareness and delinquent behaviour among secondary school students' in Obio-Akpor Local Government Area.

2) Find the extent of the relationship between social awareness and delinquent behaviour among secondary school students' in Obio-Akpor Local Government Area.

3) Examine the extent of the relationship between emotional maturity and delinquent behaviour among secondary school students' in Obio-Akpor Local Government Area.

\subsection{Research Questions}

The following research questions were postulated to guide the study.

1) What is the relationship between self-awareness and delinquent behaviour among secondary school students' in Obio-Akpor Local Government Area?

2) What is the relationship between social awareness and delinquent behaviour among secondary school students' in Obio-Akpor Local Government Area?

3) What is the relationship between emotional maturity and delinquent behaviour among secondary school students' in Obio-Akpor Local Government Area?

\subsection{Hypotheses}

The following hypotheses stated in a null form were postulated for the study and tested at 0.05 alpha level.

$\mathbf{H}_{01}$ : There is no significant relationship between self-awareness and delinquent behaviour among students in public secondary schools in Obio-Akpor Local Government Area?

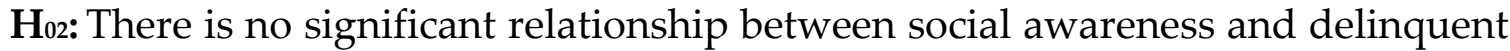
behaviour among students in public secondary schools' in Obio-Akpor Local Government Area? 
$\mathrm{H}_{03}$ : There is no significant relationship between emotional maturity and delinquent behaviour among students in public secondary schools' in Obio-Akpor Local Government Area?

\subsection{Study Area}

This study was conducted in Obio-Akpor Local Government Area of Rivers State in Nigeria and the African continent. The local government is one of the 23 local governments in Rivers State with having its Headquarters at Rumuodomaya and it is peopled by the Ikwerre subgroup of the Igbo speaking people. It is situated in the southern part of Nigeria. The Local Government Area covers $260 \mathrm{~km}^{2}$ and it is bounded by four local governments namely: Ikwerre, Eleme on the East, Asari-Toru on the West and Okirika on the South. The inhabitants speak mainly Ikwerre and English language. There exist inflow and outflow movements of people. It is one of the mainland local governments in the state. The local government is made up of 15 secondary schools both in the rural and urban areas. Census of 2016 showed that people constituted the entire population of 464,789 (from Wikipedia).

\section{Review of Literature}

\subsection{Conceptual Review}

\subsubsection{Emotional Intelligence (EI)}

The term "emotional intelligence" is seen as the ability of an individual to appropriately and successfully respond to a vast variety of stimuli being elicited from the inner self and the immediate environment (Chadha, 2009). Goleman (1995) who popularized the term emotional intelligence claimed that emotional intelligence can be as powerful as an intelligent quotient (IQ). He explained that emotional intelligence creates passion, confidence, friendliness, motivation, pride and energy in an individual. Vanrooy and Visvesvaran (2014) viewed emotional intelligence as the set of abilities-verbal and nonverbal that enables a person to generate, recognize, express, understand and evaluate their own and other emotions in order to guide their thinking and actions and successfully cope with environmental demands and pressures.

Emotionally intelligent people or individuals use their emotions to engage in intelligent thoughts and also possess the ability to think intelligently about their emotions (Mayer et al., 2000). The conceptualization and definitions above show the pivotal role of emotional intelligence in our individual lives and if practiced by couples in their marriage, will help them to adjust. The study of emotional intelligence was developed from the works of Gardner (1983) and Williams and Sternberg (1988), who proposed broader methods to appreciate emotional intelligence.

Ikpesu (2017) opined that Salovey and Mayer (1990) coined the term "emotional intelligence" and included Gardner's intrapersonal and interpersonal components in the construct. Goleman (1998) popularized emotional intelligence in the business realm by describing its importance as an ingredient for successful business careers and as a crucial 
component for effective group performance. These theorists and many others defined and explained the concept of emotional intelligence. Emotional intelligence (EI) represents the starting point of human relationships. The process of emotional intelligence development improves both identification and mastery skills of own emotions and the ability to recognize the emotions of others. Characteristics of EI have been tested in many categories, with the aim of proving its need and the compensations for improving it. Others made researches against EI, with the purpose of proving that success is based on hard skills, not on soft skills (Ikpesu, 2017). The characteristics of emotional intelligence and its importance in marriage shall prove the necessity of two individuals with a high level of these competences. Highlighting ways of identifying and applying emotional intelligence in the marital journey would help couples in their homes.

Emotional intelligence as defined by Salovey and Mayer (1990) is the ability to monitor one's own and others' feelings and emotions, to discriminate among them and to use this information to guide one's own thinking and actions. According to them, an individual is considered to be emotionally intelligent if the same individual is able to decipher and understand not only his own feelings but that of others as well and capable of reconciling the two and applying the outcome in his operations in order to make a positive impact and have success in whatever is involved. Goleman explained that emotional intelligence has to do with the capacity to identify and discover one's own feelings and those of other person's and at the same time motivating oneself, building and keeping a check on one's feelings and using it well in relationships and in controlling outbursts.

Emotional intelligence is "an array of non-cognitive capabilities, competencies and skills that influence one's ability to succeed in coping with environmental demands and pressures that directly affects one's overall psychological well-being" (Bar-On, 1997). Thus, there is every need to understand or perceive emotions correctly and be able to regulate them in order to function maximally both cognitively and in skills or competencies.

Mayer and Salovey (1990) extensively discussed emotional intelligence, as well as the ability to identify and control emotions, identifying four separate skills such as emotion perception, understanding of information, use of information and managing emotions.

Essentially, emotional intelligence improves an individual's psycho-social adjustment with effective grouping. The higher the emotional intelligence indicates the better social and group living. Emotional intelligence is as described by Ikpesu (2017) is a master aptitude, a capacity that profoundly affects all other abilities, either facilitating or interfering with them.

\subsubsection{Elements of Emotional Intelligence (EI)}

According to Daniel Goleman (2004) an American psychologist who helped to popularise emotional intelligence, there are five key elements believed to contribute to emotional intelligence and they include empathy /managing emotions or understanding emotions, self-awareness, social awareness or social skills, self-management and self-motivation. 
- Empathy: The ability to accurately perceive emotions in others and sense what they are feeling. This, therefore, involve using emotions with feelings to enhance thinking and decision making. Managing emotions and those of others. Understanding emotions with the ability to know what causes various emotions, what they mean and how they affect behaviour.

- Self-awareness: is a component of emotional intelligence that indicates knowing one's feelings and emotions that is recognizing a feeling as it happens. It is the ability to monitor feelings from moment to moment. It involves recognizing one's emotions and their effects, accurate self-assessment which involves knowing one's emotions and their effects and self-confidence which refers to a strong sense of strength and limit (Hein, 2009).

- Self-management: This is the ability to regulate distressing effects such as anger and depression. Goleman (1995) stated that handling feeling in an appropriate way helps to build self-awareness and that people who are low in this ability are prone to feelings of distress, whereas those who are high are more resilient to life's setbacks and upsets. It involves self-control (i.e. keeping disruptive emotions and impulses in check), trustworthiness, (maintaining a standard of honesty and integrity, being sincere and faithful), conscientiousness (taking responsibility for personal performance), adaptability (flexibility in handling change or being fitted in with comfort in any environment or situation) and innovation (being comfortable with novel ideas, approaches, and new information (Wu \& Stemler, 2018).

- Self-motivation: is yet another dimension of emotional intelligence. It is the tendency to regulate or facilitate one to reach goals and improve marital satisfaction.

- Social Skill/ Awareness: emotional intelligence comprises the skill of empathy and is the most important skill which makes couples well suited for the maintenance of a peaceful home. In the words of Petrides and Furnham (2000), social awareness includes empathy, (awareness of others feelings, needs and concerns, sensing others' feelings and perspectives, and taking an active interest in their concern), service orientation (anticipating, recognizing and meeting others' needs) and organizational awareness- reading a group's emotional currents and power relationship.

\subsubsection{Delinquent Behaviour}

Delinquent means offending by neglect or violation of duty or of law (Merrian Webster, online dictionary). Any act of disobedience or non-compliance to rules and regulations can be termed delinquent. Delinquency or delinquents refers to a person who commits a misdemeanour. On the other hand, behaviour can be seen as the way somebody acts, especially towards other people. Nwankwo (2011) noted that conceptualized behaviour as covert and overt in nature. Covert behaviour he said is that which is not directly observable by organisms or persons around but can be psychologically perceived only 
by the organisms which are reacting to the internal environment. Typical examples of covert behaviour include beliefs, thinking, emotional feelings (both the positive and negative types), attitudes particularly the cognitive and emotional components, perceptions, and all other internally or psychologically rooted activities of organisms. On the other hand, he referred to overt behaviour as the activity of the organisms which is physical and external and can be directly observed. Examples: talking, reading, writing, walking, jumping, laughing, sleeping, snoring and fighting, among others. From this perspective, behaviour refers to any overt (observable) response or activity by the organisms (Weiten 2004, pg.6) in Nwankwo 2011.

The development of such traits occurs through a combination of environment, genetics, and individual differences (Hogg \& Cooper, 2007). Genetic and environmental influences appear to vary significantly depending on whether or not the behaviours displayed by an individual are aggressive or non-aggressive. Genetics seem to factor in more for aggressive behaviours (65\% versus $45 \%$ ), and shared environment accounts more for non-aggressive behaviours (18\% versus 5\%) (Burt, 2009). Delinquent behaviours, though, consistently have been shown to be comprised of both aggressive and non-aggressive behaviours.

Aggressive behaviours are more consistent over time and occur more frequently within the toddler years. Non-aggressive behaviours are more frequent during adolescence. Individuals who display high levels of aggression in childhood tend to be aggressive in adulthood as well; the stability of this trait is comparable to intelligence (Burt, 2012). Although most individuals engage in delinquent behaviours at some point in their lives, usually during adolescence, the behaviour remains temporary and does not persist into adulthood (Moffitt, 1993). Delinquent behaviours are actually quite common in adolescence, with about $80 \%$ of all adolescents exhibiting some delinquent behaviours, but they do not occur as frequently in children (Blazei et al., 2006). Aggressive behaviour appears to be highly genetic with little influence from a shared environment. Nonaggressive behaviour is also influenced by genetics, but much less so than aggressive behaviour. Additionally, non-aggressive behaviour is influenced by the environment (Burt, 2012). As discussed in Chapter 1, Moffltt's (1993) theory proposes two types of delinquent behaviours: life-course persistent, which start early in childhood and persists throughout one's life, and adolescent-limited, which starts in adolescence and ends by adulthood.

Barriga and Gibbs (1996) examined what they called "self-serving cognitive distortions" and how these contributed to aggression. The researchers identified two types of distortions: primary and secondary. Primary distortions include egocentric attitudes and belief biases: according to one's own views, expectations, needs, rights, and immediate feelings and desires to such a degree that the legitimate views, etc. of others (or even one's own long-term best interest), are scarcely considered or are disregarded altogether (p. 334). Secondary cognitive distortions are "pre- or post-transgression rationalizations that serve to 'neutralize' conscience or guilt, and thereby to prevent damage to the self-image following delinquent behaviour". This includes blaming others, particularly other 
persons or groups, minimizing one's own behaviour and its effects, and presuming the worst in social situations.

Conclusively, delinquent behaviour is the conduct, deportment, or comportments which is not acceptable or conform to the norms of a given society. The American Psychological Association defines the term delinquency behaviour as "denoting or exhibiting behaviour that sharply deviates from the social norms and also violates other people's rights", and cites arson and vandalism as examples of such behavior. Delinquent behaviour and aggression are often understood by experts through a developmental perspective.

\subsection{Theoretical Review}

The work was hinged on three theories: social learning theory, General theory of Crime and Ability Measures theory of emotional intelligence.

\section{- Social Learning Theory}

The Social Learning Theory as postulated by Sir Albert Bandura, proposes that people learn by observing and imitating the behavior of others, this implies that social behaviours are learned, aggressive behaviours are cultured through observing such behaviour in others (Bandura, Ross, \& Ross, 1961). In his famous "Bobo doll" experiment, Bandura observed that children who were exposed to an aggressive model (an adult participant who behaved aggressively toward the Bobo doll toy) were far more likely to imitate the model's behaviour than were children who were not exposed to the aggressive model. In society, children frequently come into contact with influential models, such as parents, peers, teachers, and characters on television. Children attend to these models, observing and then encoding their behaviour.

Children are more likely to attend to and then copy behaviour if the child identifies with the individual engaging in the behaviour. The child's behaviour, then, is either rewarded or punished by the people around him or her. If the imitated behaviour is rewarded, or reinforced, the child is encouraged to perform the behaviour again. The reinforcement can be external, such as from one's parents, or internal, such as whether the child feels happy about the approval. The reinforcement can also be positive or negative, but it must align with the child's needs.

Social Learning Theory also suggests that children consider the effect a behaviour has on others before they decided to imitate the behaviour. In this way, children can be reinforced vicariously. For example, if a sibling is praised for a particular behaviour, the child then is more likely to copy the behaviour. Children learn to identify with numerous people, such as parents, siblings, teachers, or even people in the media. In identifying with others, the child, then, attempts to adopt that individual's behaviours, beliefs and attitudes.

Bandura (1977) later asserted that individuals actively consider the relationship between what they do and the resulting actions, or consequences. This is why one does not simply notice the behaviour of another and then immediately reproduce the behaviour; there must be some consideration given. Bandura termed this the mediational 
processes, of which there are five: observation, attention, retention, reproduction, and motivation. Attention refers to how often one notices behaviour, or, how often it attracts one's attention.

Retention describes how well an individual remembers the behaviour to which he or she has been exposed. Social learning does not generally occur in an immediate fashion; it must be linked to memory. Reproduction occurs once one then reenacts a behaviour he or she has seen. Motivation refers to the individual's willingness or desire to repeat the behaviour and the rewards or punishments that coincide with that behaviour. If an individual thinks the perceived rewards will outweigh the costs, the chance of a behaviour being imitated increases.

\section{- General Theory of Crime}

Gottfredson and Hirschi's (1990) General Theory of Crime asserts there are six factors that indicate low self-control: risk-seeking, preference for physical activities, nonverbal communication, short-sightedness, volatile temper, and impulsivity. Individuals with low self-control are thought to engage in more delinquent behaviours, which, Gottfredson and Flirschi claim, could be "the" cause of crime. These individuals also tend to be insensitive to the needs of others, and so have more problems in social relationships. The theory continues on to warn about the "origins postulate", which states that parents must pay close attention to their children, and appropriately identify and discipline bad behaviour. If a child has not developed self-control by age eight to ten, it may be unlikely to ever develop. As a result, the authors consider self-control a trait that stays relatively stable throughout one's life.

Over the years, researchers have raised issues with this theory's generalizability and accuracy. Ha and Beauregard (2016) pointed out three main concerns regarding the theory. First, Gottfredson and Hirschi posited that low self-control most likely contributes to one's participation in crime when that individual is exposed to crime opportunities, however, the opportunity for crime has rarely been studied in relation to this theory, with self-control dominating most discussions. Second, most research regarding this theory has not focused on samples with high levels of criminality, so it is difficult to generalize the findings to populations with higher crime rates and more severe behaviours. Third, studies that test the General Theory of Crime have chosen to examine how low self-control contributes to involvement in criminal activity. These studies, though, have not assessed how low self-control relates to the different factors involved in the process of committing a crime. Gottfredson and Hirschi pointed out that situational factors and individual traits could also affect self-control, and so it should follow that these other conditions and propensities are taken into consideration.

\section{- The Ability Measures Theory of Emotional Intelligence}

Ability measures see Emotional intelligence as the combination of different skills: the ability to perceive accurately, appraise, and express emotion; the ability to access and or generate feelings when they facilitate thought; the ability to understand emotion and 
emotional knowledge; and the ability to regulate emotions to promote emotional and intellectual growth. (Salovey \& Sluyter, 1997).

To some studies, ability El differs significantly with gender, with women performing better than men. However, effect sizes in these studies also vary. Some studies show low effects (e.g., Fernández-Berrocal, Cabello, Castillo, \& Extremera, 2012), and some show medium effects (Farrelly \& Austin, 2007). Cabello and FernándezBerrocal (2015) sought to discover how emotions and El are related, and how much people perceive them to be changeable. The authors also examined how implicit theories of emotion and El are associated with ability El. Implicit theories "function like knowledge structures, through which people interpret themselves and others" (pg. 2). Individuals often keep their behaviour in compliance with these knowledge structures, and so such theories can have a large impact on one's behaviour, and may account for why different people respond differently to the same stimuli or even therapy. People hold differing views on the possibility of change in regards to cognition, emotions, and behaviour, and this can affect many areas, such as intelligence, emotion, social skills, relationships, management, judgment, and stereotyping (Dweck, 2012).

\subsection{Empirical Review}

\subsubsection{Relationship between self-awareness and delinquent behaviour among school students}

Grant, Potenza \& Desai (2011) conducted a research on self-awareness and fighting among high school students: prevalence and clinical correlates a large sample of high school students $(n=3999)$ was examined using a self-report survey with 153 questions concerning demographic characteristics, fighting behaviours, other health behaviours including substance use, and functioning variables such as grades and violent behaviour. The overall prevalence of fighting was $15.2 \%$ (95\% (I: $14.8-17.0)$ twenty-nine $(0.72 \%)$ students endorsed symptoms constituent with a diagnosis of DSM-IW kleptomania. Poor grades, alcohol and drug use, regular smoking, sadness and hopelessness, and other antisocial behaviours were all significantly $(\mathrm{P}<.05)$ associated with any fighting behaviour, fighting appears fairly common among high school students and is associated with a range of potentially addictive and antisocial behaviours. Significant distress and loss of control over the behaviour suggest that fighting offer has significant associated morbidity.

Grant, et al. (2011) researched stealing among high school students: prevalence and clinical correlates, whereas this study will focus on the relationship between emotional intelligence and delinquent behaviour of which fighting is one of the variables among secondary school students.

Feinberg, Evola and Barchard (2005) carried out a research on the relationship between self-awareness, Emotional Intelligence and drug abuse. A total of 99 participants were used in this research, (43 male, 53 female and 3 unspecified). Ages ranged from 1852 with a mean of 21.7 and a standard deviation of 5.1. The survey of Emotional 
Intelligence (Ten, Wang and Fox 2003; Tett, Wang, Gribler and Martinez 1997) contains 12 sub-scales items used: a modified 4- point Likert-type rating scale, with 1 indicating "strongly agree" and 4 indicating "strongly disagree".

Drug abuse was measured using a single item, counting the number of days participants took depressants or stimulants in the last 30days. First, they asked how often the participant has taken drugs in the last 30 days due to whatever reason. Then they asked how many times they did not work for other reasons. This latter item measured drugs for reasons other than sickness and was the focus of their analysis. Data were collected during two sessions held one week apart and supervised by trained research assistants. The measures were all administered over the computer. They concluded that there is indeed some relationship between emotional intelligence and drug abuse among the participant

Salguero et al. (2014) indicated a negative association between perceived El and drug use in women but found no significant correlations in relation to ability El. There was also a significant correlation between ability $\mathrm{El}$ and perceived El, indicating that women with higher El levels do not always see themselves as having high emotional skills, but this correlation was low to moderate. Women seemed to be less dependent on drugs only if they had high scores in both ability El and perceived El. Perceived El seemed to explain drugs in women in that it enhances the influence of ability El.

\subsubsection{Relationship between social awareness and delinquent behaviour among secondary school students}

Ortiz (2012) studied the Association between Emotional Intelligence and Sexual Risk Behaviour among Undergraduate College Students in the Greater Los Angeles. The purpose of this study was to examine the relationship between emotional intelligence, and sexual, smoking, and alcohol behaviour among young adults. As well as explore the relationship between health risk behaviours. Emotional intelligence and sexual, alcohol, and smoking behaviour of undergraduate college students from the greater Los Angeles area was assessed through an anonymous online questionnaire (n80). There was no significant difference found in emotional intelligence between college students engaging in risk behaviours and college students not engaging in risk behaviours, for all risk behaviours assessed. However, there was a strong correlation found between college students' engagement in different risk behaviours. These results indicate there is no significant relationship between emotional intelligence and health risk behaviours. Research about this relationship can be useful in designing interventions that reduce negative health outcomes associated with health risk behaviours.

Empirical researches on social awareness have aligned with Bandura's theory, providing support for the idea that aggression in adolescents is associated with aggression in parents. In a study of 292 junior and high school students $(46.7 \%$ male, $53.3 \%$ female; $13-18$ years of age), Winstok and Perkis (2008) that aggressive tendencies of both genders were associated with aggressive tendencies in both same-gendered parents and close friends. Participants were asked to complete an assessment regarding 
their intentions to react to aggression (Winstok \& Enosh, 2007), and then were asked to respond to similar questions regarding the intentions to react to the aggression of their parents. The findings followed Bandura's notion that one learns from others through observation, modeling, and imitation. This also aligns with previous research on Bandura's theory, which asserted children are more likely to model and imitate their same-sex parents (Bandura \& Walters, 1963; Perry \& Bussey, 1979).

Expanding upon Bandura's theory, Tapper and Boulton (2005) sought to examine the ways in which children are rewarded for their aggressive behaviour, and how these rewards vary by gender. In their study of 77 children in British primary schools (ages 78 and 10-1 1). Children were observed for aggressive behaviour and victim and peer responses. Researchers witnessed a total of 125 acts of physical aggression, 278 acts of direct verbal aggression, 137 acts of direct relational aggression, and 52 acts of indirect relational aggression. Results indicated that direct aggression brought about retaliation or withdrawal from victims. Both direct and indirect aggression led to peer support for the aggressor. Acts of physical aggression seemed more likely to take place in the absence of one's peers. It appears, then, in this sample, direct aggression was positively reinforced by one's peers, and negatively reinforced by Victims. An analysis of gender differences suggested that girls were more often positively reinforced than boys for both direct relational aggression (70\% versus $40 \%$ ), and direct physical aggression (44\% versus 36\%).

\subsubsection{Relationship between emotional maturity and delinquent behaviour among secondary school students}

Lomas, Stough, Hansen \& Downey (2012) also examined for the first time the relationship between emotional intelligence of adolescents, bullying behaviours and peer victimization using a sample of 68 adolescents from a secondary college. Participants completed a self-report questionnaire that assessed their emotional intelligence, how frequently they engaged in bullying behaviours and how often they were the target of peer victimization. The result of the study indicated that the bully peer relations dimension of understanding the emotions of others (UEO) $R=-21, P<0.01$ ), indicating that participants with lower levels of UEO reported more frequent bully behaviours than those with higher levels of UEO. Thus, adolescents with a lesser understanding of the emotions of others may find it difficult to understand the consequences of their actions and not comprehend the adverse impact their bullying behaviour has on others.

Martos, Lopez-Zafra, Pulido-Martos, and Augusto (2013) conducted a study to examine the relationship between El, self-monitoring and empathy on students' maladaptive behaviour.

Vogel (2006), in her doctoral dissertation at Northcentral University in Arizona, studied the relationship between bullies, their victims and emotional intelligence, and found that as many as $23 \%$ of school children report being bullied over a three-month period. Stacy's study included 235 fourth and fifth-grade students who were tested with the bully/victim questionnaire and the Emotional quotient inventory. The study supported a relationship between emotional intelligence and bullying, but not as 
complete as expected, but failed to support a prediction that gender would moderate the emotional intelligence - bully relationships. The interpersonal scale was significantly related to the bully's scores, but not that of the victims scores.

The results from Cabello and Fernández-Berrocal's (2015) study suggested that implicit theories of emotional maturity affect total ability El on the Mayer-SaloveyCaruso Emotional Intelligence Test (MSCEIT; Mayer, Salovey, \& Caruso, 2002). This study included 688 adults (37\% male, 63\% female; 19 to 73 years of age). Participants were asked to complete the MSCEIT, the Implicit Theories of Emotion Scale (Tamir, John, Srivastava, \& Gross, 2007), and an adapted version of the Implicit Theories of El scale (Dweck, 1999). The authors found that those individuals who feel people can control and change their emotions ('incremental theorists') have higher emotional maturity, indicating that if one believes he or she can alter emotions, he or she is more likely to use effective strategies for coping. These incremental theorists also tended to have fewer negative emotions. Results from this study can be useful for interventions because it indicates that emotions may be changeable depending upon circumstance or coping strategy.

\section{Research Method}

The research design of the study was correlational research design. The population of the study consisted of the students of the 20 senior secondary schools in Obio-Akpor local government area with a population of 17,227 . The simple random sampling technique was used to select 10 secondary schools within the area of study. From the 10 schools selected for the study, sample random sampling was used also to select 24 students from each of the 10 schools selected. Thus, a total of 240 students was the sample size used for the study. The instrument for data collection was a self-structured questionnaire titled "Emotional Intelligence and Delinquent Behaviour Inventory" (EIDBI) It consisted of two sections, A and B. Section A provide demographic data of the respondents such as gender, class, name of school and address. Section B consisted of "Students' Emotional Intelligence Inventory" (SEII) and "Students' Delinquent Behavour Inventory" (SDBI). The SEII contained 30 items while the SDBI contained 15 items designed to elicit responses to examine the students' emotional intelligence and students' delinquent behaviours. It is structured in a four (4) point modified Likert type scale of Very High Extent $(\mathrm{VHE})=4$, High Extent $(\mathrm{HE})=3$, Low Extent $(\mathrm{LE})=2$, and Very Low Extent (VLE) $=1$. The instrument passed face and content validity; the reliability of the instrument was determined through the use of the Cronbach Alpha Method. A trial test of the instrument was administered to 30 public secondary school students randomly selected who are from other local government areas of the state (Ahoada-West and Port Harcourt Local Government Areas). Scores were obtained and correlated using Cronbach Alpha analysis. The overall reliability indices stood as follows; SEII $(r=0.67)$ and SDBI $(r=0.80)$ was obtained. The instrument was considered reliable for the study. The researcher administered the instrument with the help of five trained research assistants. The 
instrument was given to respondents in the schools selected. The researcher with the assistants sought permission from school heads, administered the instruments and revisited the schools after two weeks to retrieve the filled instruments. Pearson Product Moment Correlation PPMC) was used to answer all the research questions and also used to test all the hypotheses. The results of the hypotheses were tested for significance at 0.05 alpha level.

\section{Analysis of Data}

Research Question One: What is the relationship between self-awareness and delinquent behaviour among secondary school students' in Obio-Akpor Local Government Area?

Hypothesis One: There is no significant relationship between self-awareness and delinquent behaviour among secondary school students' in Obio-Akpor Local Government Area.

Table 4.1: Pearson's Product Moment Correlation of the Relationship between Self-Awareness and Delinquent Behaviour among Secondary

School Students' in Obio-Akpor Local Government Area

\begin{tabular}{|c|c|c|c|}
\hline \multicolumn{4}{|l|}{ Correlations } \\
\hline & & Self-awareness & Delinquent Behaviour \\
\hline \multirow[t]{3}{*}{ Self-awareness } & Pearson Correlation & 1 & 0.06 \\
\hline & Sig. (2-tailed) & & 0.37 \\
\hline & $\mathrm{N}$ & 240 & 240 \\
\hline \multirow[t]{3}{*}{ Delinquent Behaviour } & Pearson Correlation & 0.06 & 1 \\
\hline & Sig. (2-tailed) & 0.37 & \\
\hline & $\mathrm{N}$ & 240 & 240 \\
\hline
\end{tabular}

Source: SPSS Computation, 2021.

Table 4.1 showed the extent of the relationship between self-awareness and delinquent behaviour among secondary school students' in Obio-Akpor Local Government Area. As such, the answer to research question one is that the relationship that exists between selfawareness and delinquent behaviour among secondary school students' in Obio-Akpor Local Government Area is very weak $(r=0.06)$. The implication of this result is that the extent of the relationship between self-awareness and delinquent behaviour among secondary school students' in Obio-Akpor Local Government Area is very weak since the correlation coefficient $(r=0.06)$ is within the range of $r \leq \pm 0.01$ to \pm 0.19 .

Furthermore, Table 4.1 showed that the test to hypothesis one indicated that there is a very weak correlation $(r=0.06, r \leq \pm 0.01$ to \pm 0.19$)$, between self-awareness and delinquent behaviour among secondary school students' in Obio-Akpor Local Government Area. Thus, since $\mathrm{p}$-value $=0.37>0.05$, there is no significant relationship between self-awareness and delinquent behaviour among secondary school students' in Obio-Akpor Local Government Area, hence null hypothesis one is retained at the 0.05 significance level. 
Research Question Two: What is the relationship between social awareness and delinquent behaviour among secondary school students' in Obio-Akpor Local Government Area?

Hypothesis Two: There is no significant relationship between social awareness and delinquent behaviour among secondary school students' in Obio-Akpor Local Government Area.

Table 4.2: Pearson's Product Moment Correlation Analysis on the

Relationship between Social Awareness and Delinquent Behaviour among Secondary School Students' in Obio-Akpor Local Government Area

\begin{tabular}{|l|l|c|c|}
\hline \multicolumn{2}{|l|}{ Correlations } & Social Awareness & Delinquent Behaviour \\
\hline \multirow{3}{*}{ Social Awareness } & Pearson Correlation & 1 & 0.07 \\
\cline { 2 - 4 } & Sig. (2-tailed) & & 0.27 \\
\cline { 2 - 4 } & $\mathrm{N}$ & 240 & 240 \\
\hline \multirow{3}{*}{ Delinquent Behaviour } & Pearson Correlation & 0.07 & 1 \\
\cline { 2 - 4 } & Sig. (2-tailed) & 0.27 & 240 \\
\cline { 2 - 4 } & $\mathrm{N}$ & 240 & \\
\hline
\end{tabular}

Source: SPSS Computation, 2021.

Table 4.2 showed the extent of the relationship between social awareness and delinquent behaviour among secondary school students' in Obio-Akpor Local Government Area. As such, the answer to research question two is that the relationship that exists between social awareness and delinquent behaviour among secondary school students' in ObioAkpor Local Government Area is very weak $(r=0.07)$. The implication of this result is that the extent of the relationship between social awareness and delinquent behaviour among secondary school students' in Obio-Akpor Local Government Area is very weak since the correlation coefficient $(r=0.07)$ is within the range of $r \leq \pm 0.01$ to \pm 0.19 .

Furthermore, Table 4.2 showed that the test to hypothesis two indicated that there is a very weak correlation $(r=0.07, r \leq \pm 0.01$ to \pm 0.19$)$, between social awareness and delinquent behaviour among secondary school students' in Obio-Akpor Local Government Area. Thus, since $p$-value $=0.27>0.05$, there is no significant relationship between social awareness and delinquent behaviour among secondary school students' in Obio-Akpor Local Government Area, hence null hypothesis two is retained at the 0.05 significance level.

Research Question Three: What is the relationship between emotional maturity and delinquent behaviour among secondary school students' in Obio-Akpor Local Government Area?

Hypothesis Three: There is no significant relationship between emotional maturity and delinquent behaviour among secondary school students' in Obio-Akpor Local Government Area. 
EMOTIONAL INTELLIGENCE AND DELINQUENT BEHAVIOUR AMONG SECONDARY

SCHOOL STUDENTS IN OBIO-AKPOR LOCAL GOVERNMENT AREA OF RIVERS STATE, NIGERIA

Table 4.3: Pearson's Product Moment Correlation Analysis on the Relationship between Emotional Maturity and Delinquent Behaviour among Secondary School Students' in Obio-Akpor Local Government Area

\begin{tabular}{|c|c|c|c|}
\hline \multicolumn{4}{|l|}{ Correlations } \\
\hline & & Emotional Maturity & Delinquent Behaviour \\
\hline \multirow[t]{3}{*}{ Emotional Maturity } & Pearson Correlation & 1 & 0.08 \\
\hline & Sig. (2-tailed) & & 0.20 \\
\hline & $\mathrm{N}$ & 240 & 240 \\
\hline \multirow[t]{3}{*}{ Delinquent Behaviour } & Pearson Correlation & 0.08 & 1 \\
\hline & Sig. (2-tailed) & 0.20 & \\
\hline & $\mathrm{N}$ & 240 & 240 \\
\hline
\end{tabular}

Source: SPSS Computation, 2021.

Table 4.3 showed the extent of the relationship between emotional maturity and delinquent behaviour among secondary school students' in Obio-Akpor Local Government Area. As such, the answer to research question three is that the relationship that exists between emotional maturity and delinquent behaviour among secondary school students' in Obio-Akpor Local Government Area is very weak $(r=0.08)$. The implication of this result is that the extent of the relationship between emotional maturity and delinquent behaviour among secondary school students' in Obio-Akpor Local Government Area is very weak since the correlation coefficient $(r=0.08)$ is within the range of $r \leq \pm 0.01$ to \pm 0.19 .

Furthermore, Table 4.3 showed that the test to hypothesis three indicated that there is a very weak correlation $(r=0.08, r \leq \pm 0.01$ to \pm 0.19$)$, between emotional maturity and delinquent behaviour among secondary school students' in Obio-Akpor Local Government Area. Thus, since p-value $=0.20>0.05$, there is no significant relationship between emotional maturity and delinquent behaviour among secondary school students' in Obio-Akpor Local Government Area, hence null hypothesis three is retained at the 0.05 significance level.

\subsection{Summary of Findings}

1) There was a very weak and no significant relationship between self-awareness and delinquent behaviour among secondary school students' in Obio-Akpor Local Government Area.

2) There was a very weak and no significant relationship between social awareness and delinquent behaviour among secondary school students' in Obio-Akpor Local Government Area.

3) There was a very weak and no significant relationship between emotional maturity and delinquent behaviour.

\subsection{Discussion of Findings}

The study investigated the relationship between emotional intelligence and delinquent behaviour among Secondary School Students in Obio-Akpor Local Government Area. However, the result in Table 4.1 showed that the extent of the relationship between self- 
awareness and delinquent behaviour among secondary school students' in Obio-Akpor Local Government Area is very weak. Furthermore, the result of hypothesis one indicated that there is no significant relationship between self-awareness and delinquent behaviour among secondary school students' in Obio-Akpor Local Government Area. Ortiz (2012) corroborated the findings of the study, in the study that revealed that there was no significant difference found in emotional intelligence between college students engaging in risk behaviours and college students not engaging in risk behaviours, for all risk behaviours assessed.

The result in Table 4.2 showed that the extent of the relationship between social awareness and delinquent behaviour among secondary school students' in Obio-Akpor Local Government Area is very weak. While the result of hypothesis two indicated also that there is no significant relationship between social awareness and delinquent behaviour among secondary school students' in Obio-Akpor Local Government Area. These findings are consistent with the study carried out by Haddad Kooshsar (2010) which revealed that delinquent adolescents with higher emotional intelligence were lower in bullying behavioural symptoms.

The result in Table 4.3 shows that the extent of the relationship between emotional maturity and delinquent behaviour among secondary school students in Obio-Akpor Local Government Area is very weak. While the result of the tested hypothesis three indicated that there is no significant relationship between emotional maturity and delinquent behaviour among secondary school students in Obio-Akpor Local Government Area. These findings are consistent with the study of Petrides, Frederickson and Furnham (2003) which revealed that high emotional intelligence participants were less engaged in fighting behaviour as against their low trait emotional intelligence counterparts.

\section{Conclusion}

The study investigated the relationship between emotional intelligence and delinquent behaviour among Secondary School Students in Obio-Akpor Local Government Area of Rivers State. However, the findings of the study indicated that self-awareness, social awareness and emotional maturity had a very weak relationship with delinquent behaviour among Secondary School Students in Obio-Akpor Local Government Area of Rivers State. The implication of this result is that the lack of the variables in the study (self-awareness, social awareness and emotional maturity) show a high extent of the relationship with delinquent behaviour.

Based on the findings, it can be concluded that one of the most important concerns of society is the high prevalence of delinquent behaviour among secondary school students. According to the results of the study, students' emotional intelligence can prevent them. As such, it is needful for teachers to help students to build their competences towards students' self-awareness, social awareness and emotional maturity for both intrapersonal and interpersonal aspects of their emotions. 


\subsection{Recommendations}

Considering the findings, discussion and conclusions of this study, the following recommendations are made:

1) Teachers should acquire adequate information about students' self-awareness so that they can help students in the management of their emotions and as such prevent students from engaging in the delinquent act.

2) The Ministry of Education should educate school administrators and teachers on the dynamics of emotional intelligence in order to raise awareness and prevention delinquent behavior from manifesting.

3) Policymakers should formulate educational programmes with specific reference to Emotional Intelligence that addresses students' behavioural tendencies

4) School administrators should organize life skills programmes that can educate students on the warning signs and risk factors of delinquent behaviour so as to promote early detection and reduce incidence.

5) Teachers and school administrators should encourage students to seek counselling when delinquent-triggered problems arise.

6) School administrators should emphasize the importance of students' participation in the social activities that the school offers.

\section{Conflict of Interest Statement}

The author hereby disclose that he has no conflict of interest to declare and other potentially affiliation with or involvement in any organization or entity, including specifics or non-financial interest, relationships and affiliations in the subject matter or materials discussed in the manuscripts that could interfere with the publication of the article "Emotional Intelligence And Delinquent Behaviour Among Secondary School Students In Obio/Akpor Local Government Area Of Rivers State, Nigeria" submitted and published under European Journal of Education Studies.

\section{About the Author}

Dr. Obungwah Fabianmartins holds a PhD Degree in Religious and Cultural Studies from the University of Port Harcourt, Nigeria. He also holds a Master Degree (M.Ed) in Guidance and Counselling under the Department of Educational Psychology, Guidance and Counselling from Ignatius Ajuru University of Education, Port Harcourt, Nigeria and $\mathrm{a} \mathrm{PhD} \mathrm{in} \mathrm{view} \mathrm{from} \mathrm{the} \mathrm{same} \mathrm{Department.} \mathrm{He} \mathrm{has} \mathrm{a} \mathrm{Bachelor} \mathrm{of} \mathrm{Art} \mathrm{(B.A)} \mathrm{Degree}$ from the University of Uyo, Nigeria, and another Bachelor in Theology (B. Th.) in Urban Pontifical University, Rome, Italy. His research centers on Educational Counselling and rehabilitation of persons with substance abuse disorder in formal and non-formal setting. He has contributed widely in local and international journals. His passion is on Theology and marital counselling. 


\section{References}

Angold A., Prendergast M., Cox A., Harrington R, Simonoff E., Rutter M. (1995). International Journal of child and adolescent psychiatric assessment. 25(4):739- 753.

Chopras, B. \& Kanji, S. (2010). The relationship between emotional intelligence and abuse of alcohol marijuana \& tobacco among college students. Retrieved on 26-04-2016 from. www.cshu.edu/.../emotional intelligence.

Coleman, A. M. (2016) A dictionary of psychology. Oxford University Press.

Coleman, R. F., (Beghind M. L., Ryan J. A. M. \& Handkins, J. D. (2004). Positive youth development in the United States: Research findings on the evaluation of positive youth development programme prevention and treatment. 5 (1 5) 29-34.

Dickerson, V., \& Coyne, J. C. (1987). Family cohesion and control: A multitraitmultimethod study. Journal of Marital and Family Therapy, 13, 275-285.

Dusenberg, D. (2019). Living Microscale. Larward university press.

Goleman, D. (1995). Emotional intelligence. Baritem books.

Goleman, D. (2005) Emotional intelligence. Bentam books.

John, O. P., Naumann, L. P., \& Soto, C. J. (2008). Paradigm shift to the integrative Big-Five trait taxonomy: History, measurement, and conceptual issues. In O. P. John, R. W. Robins, \& L. A. Pervin (Eds.), Handbook of personality: Theory and research (3rd ed., pp. 114-158). Guilford Printing Press

Karban, R. (2015). Plant behaviour and communication in: Plant sensing and communication. Chicago and London. The University of Chicago press.

Lizotte, A. J., Chard-Wierschem, D. J., Loeber, R., \& Stern, S. B. (1992). A Shortened Child Behavior Checklist for Delinquency Studies. Journal of quantitative criminology, 8(2), 233-245.

Moos, R. H., Insel, P. M., \& Humphrey, B (1974). Preliminary manual for family environment scale, work environment scale, group environment scale. Consulting Psychologists Press

Moos, R. H., \& Moos, B. S. (1976). A typology of family social environments. International journal of family process, 15, 357-371.

Moos, R. H., \& Moos, B. S. (1981). Family environment scale manual. Consulting Psychologists Press.

Nkeng, B. (2005). Juvenile delinquency: The core (4th ed.) Relmonth C. A. Waldworthl Cengage Ltd. Parker R., Spears, J. \& Jones, D. (2000). Development and validation of a measure of emotional intelligence. Journal of personality and Individual Dfferences.25(3)167-177.

Norbeck, J. S., Lindsey, A. M., \& Carrieri, V. L. (1981). The development of an instrument to measure social support. Nursing Research, 30(5), 264-269.

Petrides. K. V. \& Norah F. \& Adrian F. (2002). The role of trait emotional intelligence in academic performance and deviant behavior personality and individual differences (360) 277-293. 
Rodge, E. R, Land, M. A, Lockman M, \& Zehi, C. (2002). Emotion Skills as a protective factor for Risky behaviour among college students. Journal of college student development 54(2) 172-183.

Stephenson, M. T., Hoyle, R. H., Palmgreen, P., \& Slater, M. D. (2003). Brief measures of sensation seeking for screening and large-scale surveys. Journal of drug and alcohol dependence, 72(3), 279-286.

Stains, B \& Staines, J. (2009). Juvenile delinquency and delinquent behaviour and development perspective (3rd ed) upper saddle Ruler N. J. Pearson Prentice Hall. Woolfalk, A. Hughes M. \& Walkup, V. (2002). Psychology in education. New York. Pearson.

Whiteside, S. P., \& Lynam, D. R. (2001). The Five-Factor Model and impulsivity: using a structural model of personality to understand impulsivity. Journal of Personality and individual differences, 30(4), 669-689

Wechsler, D. (1991). Weschler Intelligence Scale for Children: Third Edition manual. The Psychological Corporation Press. 

will be applied to their work. Under the terms of this license, no permission is required from the author(s) or publisher for members of the community to copy, distribute, transmit or adapt the article content, providing a proper, prominent and unambiguous attribution to the authors in a manner that makes clear that the materials are being reused under permission of a Creative Commons License. Views, opinions and conclusions expressed in this research article are views, opinions and conclusions of the author(s). Open Access Publishing Group and European Journal of Education Studies shall not be responsible or answerable for any loss, damage or liability caused in relation to/arising out of conflicts of interest, copyright violations and inappropriate or inaccurate use of any kind content related or integrated into the research work. All the published works are meeting the Open Access Publishing requirements and can be freely accessed, shared, modified, distributed and used in educational, commercial and non-commercial purposes under a Creative Commons Attribution 4.0 International License (CC BY 4.0). 